\title{
Abriendo Oportunidades a la incidencia política en mi comunidad: Guía Curricular
}

Population Council

Follow this and additional works at: https://knowledgecommons.popcouncil.org/departments_sbsr-pgy

Part of the Civic and Community Engagement Commons, Family, Life Course, and Society Commons, and the Gender Equity in Education Commons How does access to this work benefit you? Let us know!

\section{Recommended Citation}

"Abriendo Oportunidades a la Incidencia Política en mi comunidad: Guía Curricular." Guatemala City: Population Council, 2018. 


\title{
Abriendo Oportunidades ${ }^{\circledast}$ a la Incidencia Política en mi comunidad
}

\author{
CUIA CURRICULAR
}

\section{PRESENTACIÓN}

La propuesta de Abriendo Oportunidades ${ }^{\circledR}$ a la incidencia política en mi comunidad, enfatiza en la condición ciudadana de las niñas y adolescentes, impulsando su interés por comprometerse con mejoras en su comunidad a través de su participación en el diseño y ejecución de acciones de incidencia política a nivel familiar, escolar, comunitario y municipal.

Esta guía es un instrumento para las mentoras comunitarias que apoyan a las niñas y adolescentes participantes en el fortalecimiento de sus habilidades para la vida y en el desarrollo de competencias para realizar incidencia política a nivel comunitario. Siguiendo el modelo educativo de Abriendo Oportunidades $₫$ -AO- se fundamenta en el abordaje de derechos humanos, la perspectiva de género y el respeto a la identidad cultural y además construye la propuesta de incidencia política sobre dos consideraciones:

1. Las niñas y adolescentes son ciudadanas, con derechos y deberes, con la capacidad de liderar procesos de incidencia en los diversos espacios sociales en que conviven -familiar, escolar, comunitario, municipal-.

2. La incidencia política es un ejercicio ciudadano que se realiza ante autoridades políticas - quienes toman decisiones- con el propósito de transformar condiciones que limitan los derechos y el respeto a la dignidad de una persona o un grupo de personas. Su fin, debiera enmarcarse en el bien común y el reconocimiento de la dignidad de todos los seres vivos.

Se espera que mediante su implementación con grupos de niñas (8 a 12 años) y de adolescentes (13 a 17 años) liderada por mentoras comunitarias las participantes:

* Reconozcan su condición ciudadana, sus derechos y deberes frente a los ámbitos de convivencia social, política, cultural y económica.

* Se comprometan con la responsabilidad ciudadana de aportar a la transformación de las condiciones de vida que denigran la dignidad de las niñas, las adolescentes y las mujeres en sus espacios de convivencia.

\section{* Conozcan incidencia como una herramienta para planificar y liderar procesos de transformación.}

\section{* Se organicen a nivel comunitario para democratizar y acceder a los espacios de participación en la toma de decisiones.}

la

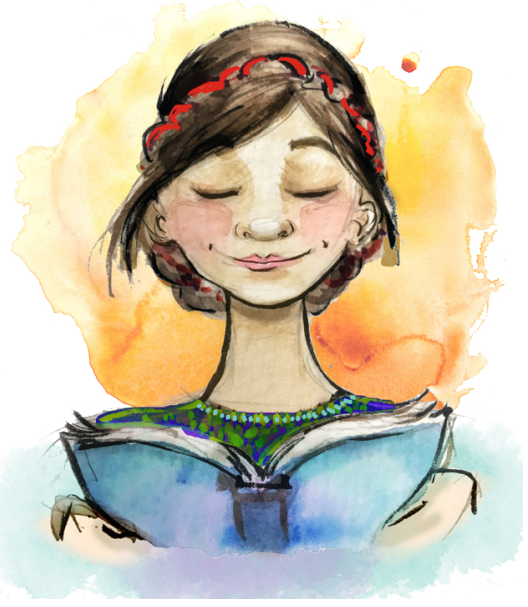


La metodología de educación popular usada en AO persigue alcanzar la construcción colectiva del conocimiento. Cada sesión se desarrolla en cuatro pasos: 1. Bienvenida 2. Introducción, 3. Definición y teorización y 4. Aplicación a la vida. El grupo inicia la sesión analizando sus experiencias de vida, luego construye colectivamente conceptos y, con apoyo de las categorías teóricas interpreta los fenómenos del entorno proponiendo medios para su transformación mediante la aplicación de ejercicio y herramientas de incidencia política.

Para que la facilitación de cada encuentro genere la convivencia necesaria para consolidar la red de amigas entre las participantes y la mentora, se siguen los siguientes principios de la educación popular:

\section{ESTRUCTURA DE LA GUITA CURRICULAR}

Este currículo se compone de tres módulos centrados en el reconocimiento de la condición ciudadana de las participantes, su derecho a la autonomía y el desarrollo de su capacidad para liderar procesos en su familia, escuela y comunidad. Al inicio de cada módulo se presenta una hoja que ofrece categorías para la comprensión del tema. Le siguen una serie de sesiones que
- Todas y todos tenemos experiencias de vida que nos permiten la construcción individual y colectiva de conocimientos.

- Todas las personas somos capaces de enseñar a y aprender de las otras y otros.

Cuando analizamos nuestras ideas y conocimientos fortalecemos nuestra autonomía y el ejercicio de nuestra ciudadanía.

- La sororidad permite el acercamiento entre mujeres para conocer nuestras experiencias, identificar nuestras diferencias, pero también comprender aquellas vivencias que compartimos.

parten de la problematización hacia el aprendizaje de ejercicios y herramientas de incidencia. Al final de la guía se presenta un breve compendio con extractos claves del marco legal que reconoce y protege la ciudadanía y los derechos de las niñas, las adolescentes y las mujeres.

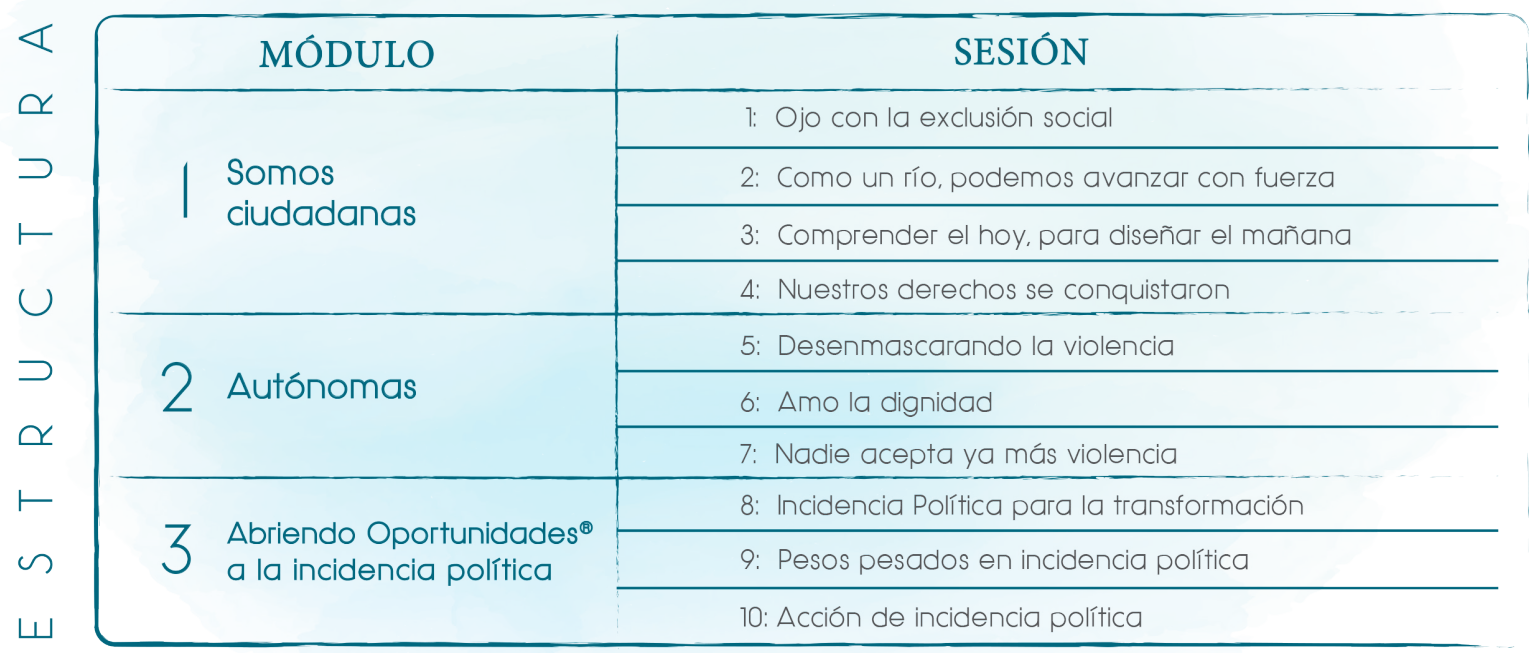




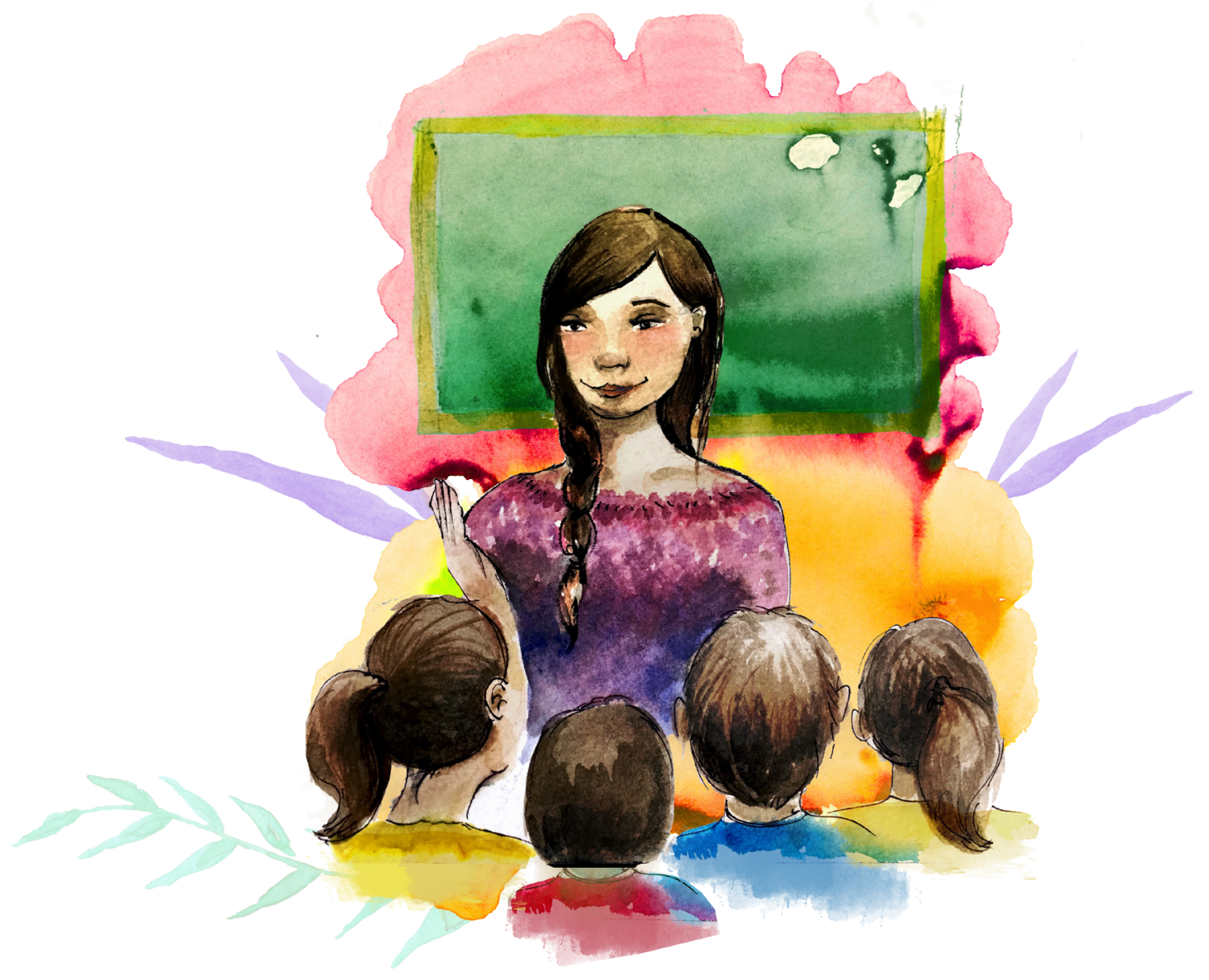

\title{
Módulo \# $\mid$ Somos ciudadanas
}

\author{
CIUDADANIA DE LAS NINAS Y \\ $A D O L E S C E N T E S$
}

"No es posible ampliar la democracia y la ciudadanía para las mujeres si éstas no se construyen como un actor social con capacidad de intervención social y negociación política"

$$
\text { - Rosa Cobo - } 2002 \text { - }
$$




\section{SOMOS CIUDADANAS}

CIUDADANÍA DE LAS NIÑAS Y ADOLESCENTES

La ciudadanía es la condición de pertenecer a una comunidad política, de sentirse parte de esta comunidad y además de ser reconocida por la comunidad como integrante de la misma. La nacionalidad, es el reconocimiento de pertenencia a la comunidad política y por lo tanto otorga a la persona los derechos y deberes que se han asignado en el marco legal de la misma comunidad. El Estado de Guatemala reconoce la nacionalidad guatemalteca a todas las personas que nacen en su territorio, así como a las hijas e hijos de guatemaltecos que nacen en otro país. Todas las que nacemos en este territorio, somos guatemaltecas y por ende somos titulares a los derechos y a los deberes que otorga la constitución y las demás leyes.

Hoy se considera que la ciudadanía es un derecho universal, pero no siempre ha sido así. En la historia de la formación de los estados ha habido etapas en las que discrimina a las personas por diferentes condiciones negándoles el reconocimiento de su ciudadanía. Esto implicó que mujeres, pueblos indígenas, personas con discapacidad $\mathrm{o}$ en condiciones de esclavitud tuvieron menos oportunidades de desarrollo y a veces ninguna posibilidad de influir en la forma en que se construyó y se vivió en su comunidad. Ni siquiera para influir en decisiones que afectaban su propia vida.

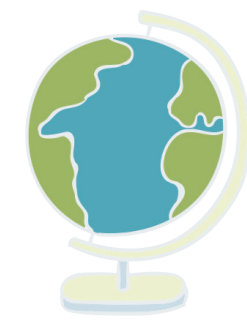

La CIUDADANÍA COMO DERECHO UNIVERSAL ES UNA CONQUISTA SOCIAL. En Guatemala numerosas mujeres lucharon durante mucho tiempo para que fueran reconocidos sus derechos: a la educación, al voto, al liderazgo y a la participación política; para influir en decisiones estratégicas de la manera en que se organiza y funciona el estado. Ser ciudadanas significa que somos niñas, adolescentes y mujeres con deberes a cumplir y derechos que deben ser respetados y garantizados por formar parte de esta comunidad.

\section{La ciudadanía como derecho universal es una conquista social.}

Cuando estamos conscientes de que pertenecemos a una comunidad organizada políticamente, reconocemos nuestra importancia dentro de la misma y asumimos el derecho y la responsabilidad de aportar en la mejora de la vida de la comunidad mediante una participación reflexiva y con acciones en el espacio público para resolver problemas comunes ejercemos la ciudadanía activa. LAS CIUDADANAS ACTIVAS OBSERVAN SU ENTORNO, IDENTIFICAN PROBLEMAS PROPIOS Y DE LOS DEMÁS, LOS DISCUTEN EN EL ESPACIO PÚBLICO PARA DEMANDAR MEJORAS Y PROPONEN MECANISMOS PARA LOGRAR ESTAS MEJORÍAS. 


\section{Definición y teorización... de conceptos clave}

Coloque a la vista del grupo el mapa de Guatemala resaltando el departamento de Alta Verapaz y señalando con un corazón el punto donde se ubica Chisec. Invite a las participantes a explicar qué es lo que ven, de qué es el mapa, cómo se llama a ese territorio, qué se encuentra en el territorio de Guatemala. Permita que quienes conocen lugares fuera de Chisec y personas que no son de Chisec pueden compartir e intentar identificarles en el mapa. También invite a que le cuenten historias de personas o lugares de fuera de Guatemala que pueden conocer y señale en los alrededores del mapa dónde se ubicaría aproximadamente.

Pida a todas que pasen al mapa y marquen con su dedo el territorio en el que nacieron. Cuando todas lo han hecho explique que van a leer el libro que contiene las normas que comparten todas las personas que viven en este territorio llamado Guatemala. Pregunte si saben ellas cómo se llama el libro que contiene el conjunto de normas y permita que hablen un poco sobre la constitución.

Lleve el texto del artículo 144 de la Constitución Política de la República de Guatemala y dirija la lectura colectiva del mismo. Con una lana de color marque un círculo en el piso y pida que se coloquen dentro del círculo todas las que son parte de la población de Guatemala. Explique que ser ciudadana es formar parte de un país, compartir con las demás personas de la comunidad los mismos derechos y deberes para asegurar que la comunidad sea un lugar que respete el bienestar de su población. Pida la participación de ellas para leer y comentar los artículos 3, 4 y 5 de la Constitución Política de la República de Guatemala. Permita que hagan sus preguntas al respecto de los artículos en mención y concluya con ellas a partir de las siguientes preguntas:

¿Cuál es su nacionalidad? ¿Qué les parece que es perfecto de Guatemala? ¿Qué les gustaría mejorar de Guatemala? ¿Quién tiene el deseo de participar en esta comunidad para mejorar Guatemala?

Formando una rueda dentro del círculo en el piso, entregue una pelota en la que ha colocado papeles con los derechos que garantiza la Constitución a la población. Pida que tiren la pelota entre ellas de forma ágil. Explique que quien bote la pelota perderá un derecho y deberá tomar uno de los papeles de la pelota. Antes de salir del círculo puede leer el derecho que perdió. Al terminarse los papeles, pida que las jóvenes de fuera compartan cómo se sintieron al estar obligadas a salirse del círculo y qué derecho fue el que perdieron. Coloque a la vista un rótulo que dice "Exclusión social" y pida que expliquen cómo se parece la situación de las niñas que perdieron derechos a la exclusión.

\section{Aplicación a la vida... para transformar nuestras circunstancias}

Pida que formen un grupo para cada uno de los derechos incluidos en los papeles. Cada grupo deberá identificar una situación en la que las niñas, adolescentes y mujeres de Chisec sufren exclusión social porque no se les respeta ese derecho. Buscarán en la constitución qué artículo reconoce ese derecho a toda la población y escribirán un gafete el derecho y el artículo que lo contempla. Presentarán a la plenaria sus gafetes. Luego de la sesión se llevarán su gafete puesto para compartirlo con las personas de su familia, escuela y comunidad. 


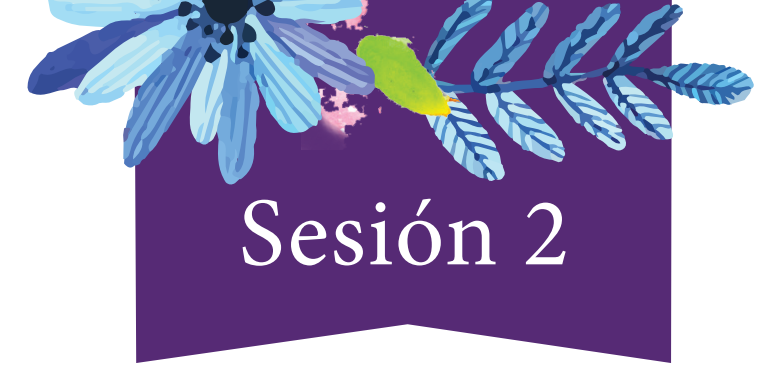

\section{Como un río, podemos avanzar con fuerza}

\section{OBJETIVOS DE LA SESIÓN:}

- Las participantes conocen los derechos de las niñas, jóvenes y mujeres indígenas.

- Las participantes comprenden que pueden influir en la toma de decisiones de su familia y comunidad para provocar cambios.

- Las participantes enumeran cambios que quieren provocar en su familia, escuela, comunidad y municipio a través de la incidencia política.

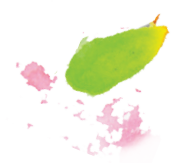

\section{DESARROLLO DE LA SESIÓN}

\section{l. Bienvenida a la sesión... Para fortalecer mi participación y pertenencia}

Dé la bienvenida a las participantes, entregando a cada una su gafete que le identifica como integrante del grupo de Abriendo Oportunidades ${ }^{\circledR}$. Pida que cada una escriba su nombre en el gafete y se presente al grupo compartiendo porqué

\section{ENFOQUE POR GRUPO:}

8 a 12: la dinámica natural de la comunidad, es tender hacia el cambio, el cambio puede ser positivo para nosotras y para nuestra comunidad si participamos en la toma de decisiones.

13 a 18: las comunidades, municipios y países cambian, hay espacios desde los que podemos participar para influir en que los cambios beneficien también a las niñas, adolescentes y mujeres indígenas.

\section{MATERIALES:}

1. Cuaderno de trabajo

2. Hojas de reuso

3. Papelógrafos

4. Marcadores y crayones

5. Afiche de los derechos de las niñas, jóvenes y mujeres indígenas quiere pertenecer al grupo de Abriendo Oportunidades para la incidencia política. Escriba usted las respuestas de cada una, en un papelógrafo titulado PERTENEZCO a Abriendo Oportunidades ${ }$. 


\section{Introducción al tema... mediante la reflexión sobre mi vida}

Pida que formen tríos de cuidado, pues saldrán a una visita en la comunidad y necesitan tener amigas entre las cuales se cuidarán. Explique que van a ir al río cercano a la comunidad, lo único que necesitan llevar es el deseo de aprender del río. Al llegar al río estarán en silencio durante un momento, observando. Mientras ellas observan usted puede motivar a la reflexión pidiendo que se fijen en algunas de las siguientes circunstancias:

- ¿Cómo cambia el agua por el cauce del río?

- ¿Cómo cambian las plantas y animales que viven alrededor y dentro del río?

- ¿Qué pasaría si el río no cambiara?
- ¿Qué fortalezas tiene el río que permiten que cambien sin destruir la armonía en su entorno?

Luego de un tiempo compartirán lo que observaron sobre el río y la forma en que cambia. Antes de retirarse pueden agradecer al río por algo que provee a su vida.

Alternativa: Si no hay un río accesible en la comunidad, puede llevar imágenes de ríos, sonidos de ríos o bien pedir a las participantes que cierren sus ojos e imaginen el río mientras usted describe cómo es un río.

\section{Definición y teorización... de conceptos clave}

En su camino de vuelta al espacio seguro los tríos se deben acercar a una persona de la comunidad para preguntarles qué cosas de la comunidad han cambiado y al llegar al espacio seguro lo dibujarán en una hoja para exponer al grupo. Luego de cada exposición pregunte al grupo cómo se realizó ese cambio, qué personas participaron en el cambio, cómo afectó el cambio a la vida en la comunidad. Apunte las respuestas de las participantes en un papelógrafo.

Recapitule todo lo que se ha platicado sobre el cambio pidiendo que escriban juntas una definición sobre qué es el cambio haciendo una lluvia de ideas. Al final enfatice en que el cambio es natural e inevitable, los cambios pueden favorecer o no, a la comunidad y somos las personas las que influimos más en los cambios que se dan. En el proceso de los cambios es importante fortalecernos con el respeto a la dignidad de las otras personas y del entorno en el que vivimos cuidando que los cambios aporten a la mejoría de la vida para todas y todos.

Presente al grupo el afiche sobre los derechos de las niñas, jóvenes y mujeres indígenas. Explique que, entre las leyes, declaraciones, convenciones se enumeran muchos derechos y estos son algunos específicos para las niñas, jóvenes y mujeres indígenas. Permita que se acerquen a ver el afiche libremente y comenten sobre cada uno. Escriba en papelógrafos de extractos del Acuerdo sobre derechos de los pueblos indígenas y la Convención de los derechos de los pueblos indígenas. Pregunte ¿Qué tienen que ver estos derechos con el cambio? ¿Qué ideas de su comunidad favorecen que el cambio se de en el respeto a las niñas, adolescentes y mujeres de la comunidad?

\section{Aplicación a la vida... para transformar nuestras circunstancias}

Pida al grupo que se divida en dos equipos de trabajo. Un equipo dibujará cómo es la situación de las niñas, jóvenes y mujeres en su comunidad actualmente. El otro equipo dibujará como debiera ser la vida de las niñas, jóvenes y mujeres en su comunidad. Al terminar ambos grupos presentarán sus dibujos enumerando las diferencias. En su cuaderno de trabajo cada una trabajará sobre la página 1 para identificar qué cambios quiere provocar en su familia, escuela, comunidad, municipio y qué fortalezas tiene ella para provocarlos. 


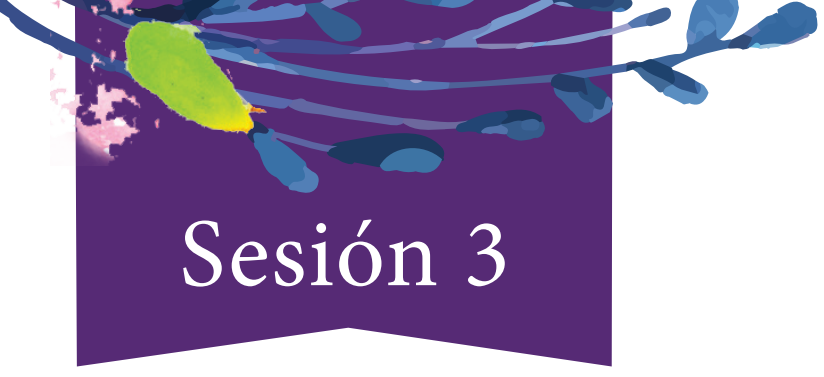

\section{Comprender el hoy, para diseñar el mañana}

\section{OBJETIVOS DE LA SESIÓN:}

- Las participantes conocen qué es la discriminación y la identifican como delito.

- Las participantes explican como un acto de discriminación por género, por edad, por pertenencia étnica, por área de residencia tiene efectos a largo plazo.

- Las participantes proponen ideas nuevas que sustituyan aquellas que permiten la discriminación en su entorno.

\section{ENFOQUE POR GRUPO:}

8 a 12: Enfatizar en las acciones en su escuela y su familia que limitan las oportunidades de las niñas, las personas con discapacidad.
13 a 18: Enfatizar las acciones de COCODES y la municipalidad que limitan el desarrollo y la participación de las mujeres indígenas.

\section{MATERIALES:}

1. Un río en la comunidad para ir a visitar o bien imágenes y sonidos de un río

2. Papelógrafos y marcadores

3. Masking tape

4. Definición de discriminación

5. 4 sobres con papeles indicando la persona que debe representar jugando

6. Cuaderno de trabajo "Nade me detiene"

\section{DESARROLLO DE LA SESIÓN}

\section{l. Bienvenida a la sesión... Para fortalecer mi participación y pertenencia}

Dé la bienvenida a las participantes. Lidere una caminata por la comunidad y pide que identifiquen las diferentes actividades que desarrollan sus pobladores con énfasis en las mujeres, las niñas, los niños, los hombres. Al regresar al salón poner a la vista un papelógrafo por los grupos de personas que vean y pídanles que escriban en cada papelógrafo qué estaban haciendo esas personas. Al final podrán comparar las diferencias en las actividades que realizan mujeres, niñas, hombres, niños, ancianas, ancianos, las adolescentes y los adolescentes. Pregunte: ¿Qué diferencia hay entre lo que hacen las niñas y niños, mujeres y hombres, adolescentes y las personas ancianas? ¿Qué personas pasan más tiempo dentro de su casa y cuáles tienen más libertad para moverse en su comunidad? 


\section{Introducción al tema... mediante la reflexión sobre mi vida}

Pida que las participantes compartan normas en su familia, comunidad, escuela, municipio y país que son diferentes para mujeres y para hombres, luego invite a que piensen para personas mayores, personas con discapacidad, personas enfermas etc. Apunte las normas en papelógrafos y al terminar pida que las lean e identifiquen si las normas fortalecen la libertad, su participación y el bienestar de las personas o si por el contario son normas que les limitan. Pueden marcar las normas con un corazón y una equis en cada caso.

\section{Definición y teorización... de conceptos clave}

Lea con ellas el concepto de discriminación en el código penal identificando con ellas las palabras clave y haciendo el traslado al q'eqchi'. Luego pueden regresar a las normas que han compartido para identificar cuáles normas son ejemplos de discriminación.

\section{Aplicación a la vida... para transformar nuestras circunstancias}

Vamos a jugar ahora el "camino a recorrer" pida la participación de 4 participantes para que pasen al frente y entregue a cada una uno de los siguientes sobres. Ellas deben compartir con el grupo, que estará observando lo que pasa con cada una, qué persona representa.

Sobre 1 titulado: niña indígena en una aldea Sobre 2 titulado: joven ladino en una aldea Sobre 3 titulado: mujer indígena en la ciudad Sobre 4 titulado: hombre ladino en la ciudad

Usted mencione oportunidades a las que todos debiéramos tener acceso, cada voluntaria considerará si la persona a la que representa tiene o no acceso a esa oportunidad. Si sí la tiene debe caminar un paso hacia adelante, si no la tiene debe quedarse en su lugar. Algunas condiciones que usted puede mencionar son:

1. Estudió la primaria

2. Estudió secundaria

3. Tiene DPI

4. Tiene licencia de conducir
5. En su trabajo recibe prestaciones

6. Tiene 15 días de descanso cada año

7. Hay una biblioteca cerca de su casa para ir a leer

8. Tiene celular inteligente con wifi para investigar

9. Ha ido al teatro a ver obras de arte

10. Cuando se enferma puede comprar su medicina antes de que sea grave

11. Cuando se enferma de forma grave puede ir al hospital donde la reciben y atienden

Discuta con el grupo ¿Qué personas se ven más limitadas? ¿En dónde están las causas de las limitaciones? ¿Qué oportunidades pierdan? ¿Cómo la discriminación le afecta a una persona a largo plazo?

En la página "Nada me detiene" de su cuaderno de trabajo, cada participante escribirá una norma de su entorno que limita su desarrollo, cómo debiera ser la situación ideal y una fortaleza que tiene para sobreponerse a ese acto de discriminación. 


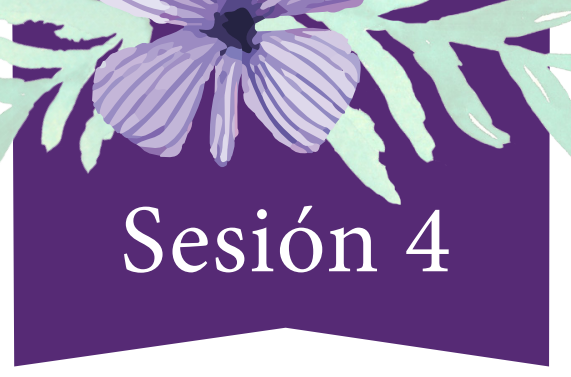

\section{Nuestros derechos se conquistaron}

\section{OBJETIVOS DE LA SESIÓN:}

- Las participantes conocen a mujeres y hombres que realizaron incidencia para que hoy todas tengamos derechos.

- Las participantes comprenden que los derechos humanos son para todas las personas (Universales), para toda la vida (Inalienables) y para hacerse cumplir en conjunto (Interdependientes).

- Las participantes seleccionan un derecho por el que quieren realizar incidencia en su comunidad.

\section{ENFOQUE POR GRUPO:}

8 a 12: Reconocen que en su familia y escuela todos y todas tienen derechos incluidas ellas. Tienen que respetar los derechos de las demás personas y hacer que se respeten los suyos.

13 a 18: Reconocen que al igual que los hombres jóvenes de la comunidad tienen derechos, que aún que no se cumplan pueden estando organizadas hacerlos cumplir.

\section{MATERIALES:}

1. Corazón de dignidad (Corazón hecho de papel para colocarse como collar)

2. Afiche de los derechos de las niñas y mujeres indígenas

3. Historias de personas que han luchado por derechos que hoy se disfrutan

4. Hoja en blanco para cada participante

5. Marcadores y crayones

\section{DESARROLLO DE LA SESIÓN}

\section{Bienvenida a la sesión... Para fortalecer mi participación y pertenencia}

Espere a las participantes en la entrada al espacio seguro, entregue a cada una un "corazón de dignidad" para que se coloquen como collar. Al estar todas juntas pida que entre ellas mencionen qué significa el corazón y qué significa la palabra dignidad. Realice el siguiente juego para que reconozcan que todas tienen dignidad. Deben colocarse en un círculo y usted se pondrá al centro dando instrucciones que ellas debe seguir. Algunas veces usted empezará la instrucción diciendo: "Niña/ joven con dignidad"; en ese caso ellas deben seguir la instrucción que usted diga. Otras veces usted dará la instrucción sin esa frase; en ese caso ellas no deben seguir la instrucción que usted diga. Por ejemplo, si usted dice “Jóvenes con dignidad brincan hasta tocar el cielo" todas deben tocar brincar para tocar el cielo; pero si usted únicamente dice: "brincan hasta tocar el cielo" no lo deben hacer pues no se llamó a las jóvenes con dignidad. Otras instrucciones que puede decir son: corran a la esquina, formen una fila, vuelen como aves, compartan abrazos entre ustedes, siéntense en el suelo, bailes como árboles...

alternando el uso de la frase "Jóvenes con dignidad...". 
Luego de jugar reflexione con ellas con base a las siguientes preguntas:

1. ¿Quiénes tienen dignidad?

2. ¿Cómo es la fuerza del grupo cuando todas reconocen su dignidad?
3. ¿Qué pasa cuando algunas no se sienten que tienen dignidad?

4. ¿Qué otros nombres podemos darle al valor que tenemos como personas?

5. ¿Quiénes tienen más dignidad y menos dignidad?

6. ¿Cómo debe ser la vida de todas las personas, porque todas tenemos dignidad?

\section{Introducción al tema... mediante la reflexión sobre mi vida}

Cuente que van a conocer la historia de algunas personas que tenían dignidad. Cuente la parte 1 de la historia de la niña Malala. Mientras la va contando puede ir haciendo pausas para reflexionar con las participantes sobre qué parecidos y diferencias hay con la vida de ellas, qué hechos afectan la dignidad de la niña Malala, cómo debieran ser las cosas para que se respete la dignidad de Malala. Las niñas pueden seguir la historia en su cuaderno de trabajo.
Al finalizar presente el afiche de los derechos de las niñas y mujeres indígenas e invítelas a señalar allí qué derechos no se respetaron en la vida de Malala; también pueden hablar sobre los derechos que son importantes en sus vidas y cómo tener unos derechos facilitan que se tenga otros.

\section{Definición y teorización... de conceptos clave}

Forme tres grupos y entregue una de las siguientes frases a cada grupo:

1. Los derechos humanos son universales. Todas las personas, de todas las aldeas, comunidades y ciudades tienen derechos porque tienen dignidad.

2. Los derechos humanos son inalienables. Las personas reciben sus derechos con su dignidad, nunca nadie les puede quitar su derecho, así como no le pueden quitar su dignidad.

3. Los derechos humanos son interdependientes. Todos los derechos son importantes. Unos derechos ayudan a que se cumplan otros derechos, si un derecho no se cumple muchos otros derechos serán limitados también.
Pida que en su grupo discutan sobre qué significa esa frase y escriban un ejemplo de cómo se aplica esa frase a los derechos de las personas de su comunidad. Cada grupo pasará a exponer la frase al frente.

Regrese al cuaderno de trabajo para conocer la parte 2 de la historia de la niña Malala. Enfatizando que frente a la limitante que le pusieron para poder estudiar ella decidió trabajar para favorecer que todas las niñas y mujeres jóvenes pudieran estudiar.

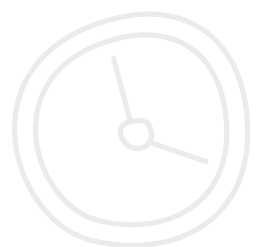

\section{Aplicación a la vida... para transformar nuestras circunstancias}

Se reunirán en grupos nuevamente en cada grupo entregue la historia de una persona que ha logrado que se reconozcan los derechos que en la actualidad tenemos. Las historias rotarán entre los grupos para que conozcan todas las historias. Luego de conocer las historias, cada una pensará qué derechos considera que le gustaría hacer cumplir en su comunidad. Realizará un dibujo de sí misma y ese derecho. En la sesión final pueden exponer todos los dibujos. 

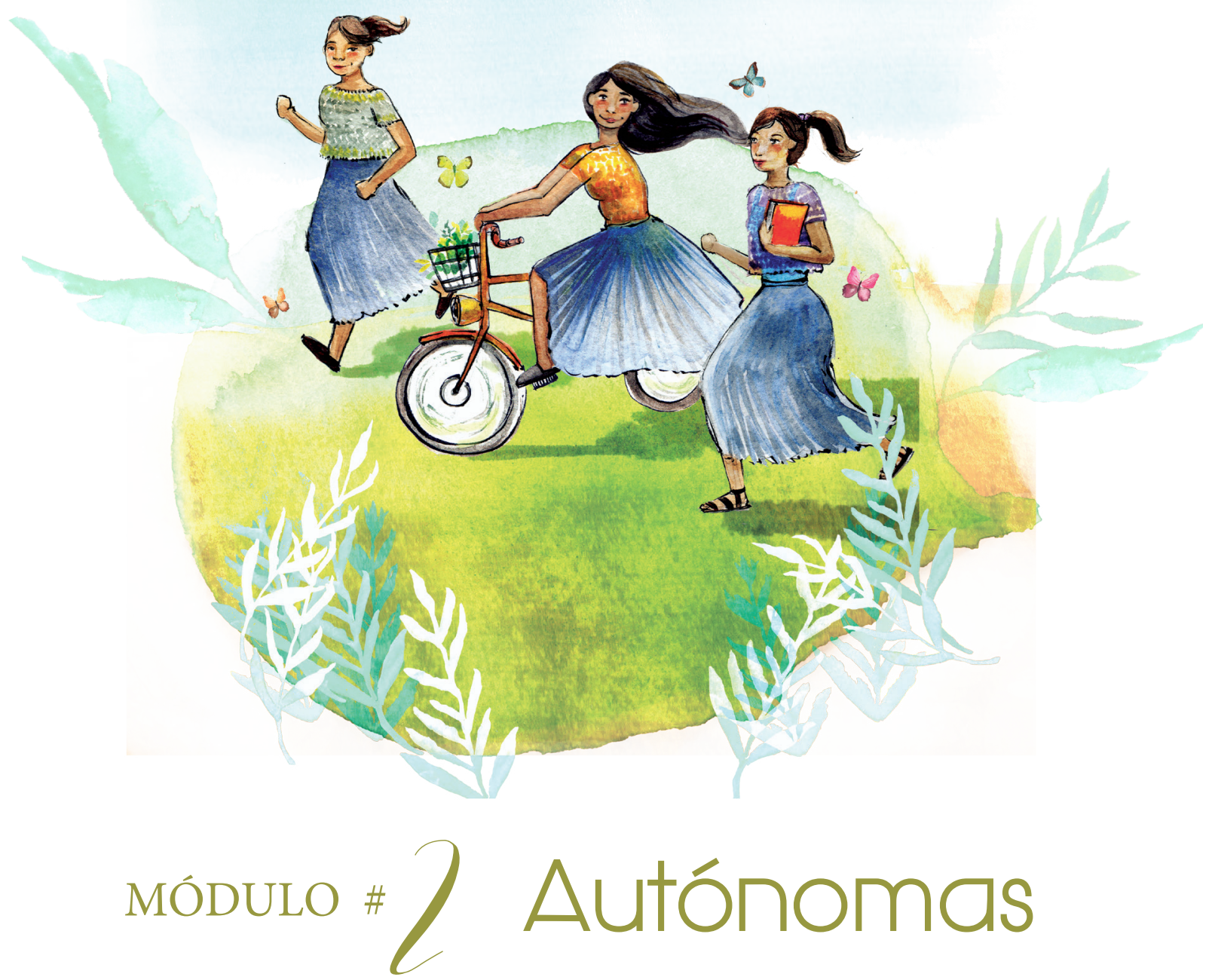

MÁs AUTONOMIA Y NADA DE VIOLENCIA

"Necesitamos hacer el inventario real de quiénes somos, qué lugares ocupamos en cada espacio, qué hacemos, para quién lo hacemos, cómo lo hacemos cuál es el sentido de lo que hacemos e ir recogiendo nuestra vida en partes" 


\section{$A U T O ́ N O M A S$}

MÁS AUTONOMÍA Y NADA DE VIOLENCIA
La capacidad de conocernos y tomar decisiones sobre nuestra propia vida se llama AUTONOMIA. Todas las personas tienen la capacidad y el derecho de ejercer su autonomía, las niñas, las mujeres, los pueblos indígenas, las migrantes, las personas con discapacidad; todas.

Ejercer la autonomía implica ser libres. Primero se necesita satisfacer las necesidades básicas comer, beber, vestirse para luego ser libre en la toma de sus decisiones. Tomar decisiones sobre la propia vida requiere conocerse plenamente, tener claridad de los valores que definen la identidad y considerarse seres integrales. En base a ello se podrán tomar decisiones, hacer planes y llevarlos a la acción. Una joven autónoma tiene la capacidad de identificar sus necesidades y las de su comunidad, satisfacer las necesidades propias y convivir en equilibrio con las demás personas de su entorno.

La autoestima forma parte de la autonomía, en la medida en la que cada mujer se valora, sabe quién es y qué desea de su vida puede confiar en sí misma para alcanzar sus metas y aportar a la comunidad. Una persona con autoestima acertada puede identificar sus valores, establecer prioridades, diseñar un plan de vida y alcanzarlo. La autoestima saludable y la autonomía se desarrollan en ámbitos seguros en los que la persona tiene sus necesidades satisfechas, se siente querida, es cuidada y respetada.

A pesar de que todas las personas tienen derecho a la libertad e igualdad según la Constitución, en la vida no siempre se reconoce a todas las mujeres su derecho a la autonomía. El patriarcado, un pensamiento antiguo compartido por muchas culturas, ha enseñado que las mujeres no tenemos las mismas capacidades y por eso deben ser los hombres -nuestros padres, parejas e incluso hijos- quienes tomen las decisiones por nosotras. Ha dado el derecho incluso de ejercer violencia en contra de las mujeres y negarles a ellas las oportunidades de satisfacer sus necesidades. Se ha comprobado que el patriarcado es un pensamiento dañino porque rompe el equilibrio en la relación entre mujeres y hombres a la vez que propicia la violencia.

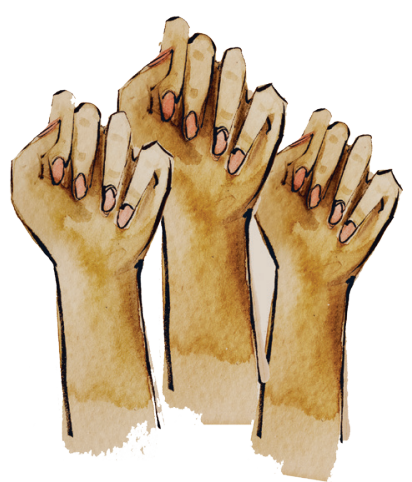

La autoestima forma parte de la autonomía, en la medida en la que cada mujer se valora, sabe quién es y qué desea de su vida

La violencia daña la autoestima y también impide la autonomía cuando se usa como una forma de controlar la conducta de las mujeres, que no seamos autónomas por miedo a las consecuencias que podamos sufrir. La violencia se puede ejercer de muchas formas y viniendo de diferentes personas, es importante que identifiquemos las formas de violencia que sufrimos las niñas, jóvenes y mujeres indígenas, así como los mensajes que la justifican para poner un fin a ella y hacer cumplir las leyes que garantizan nuestra autonomía, libertad e igualdad. 


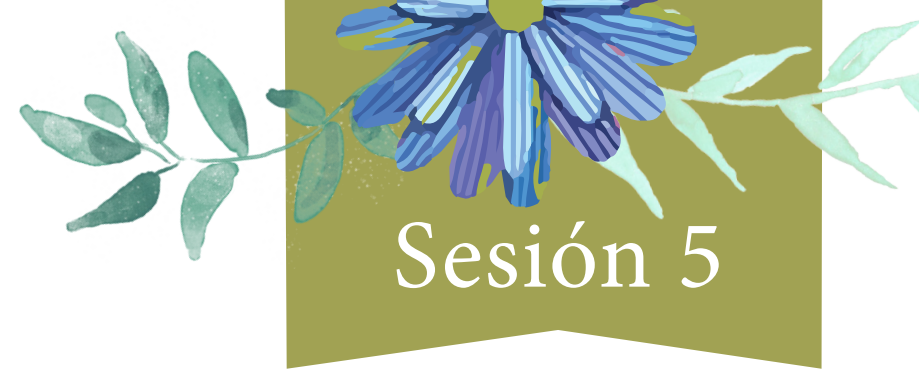

\section{Desenmascarando la violencia}

\section{OBJETIVOS DE LA SESIÓN:}

- Las participantes conocen qué es la autonomía.

- Las participantes reconocen diferentes tipos de violencia en su vida.

- Las participantes enuncian mensajes positiva sobre su autonomía y el fin de la violencia.

\section{ENFOQUE POR GRUPO:}

8 a 12: Las niñas enfatizarán las experiencias que tienen en casa, en la escuela, en los lugares públicos en las que se les han dicho mensajes y les han puesto normas que limitan sus oportunidades y les hacen daño.
13 a 18: Las jóvenes enfatizarán las experiencias que tienen en la comunidad, en su familia ampliada y en los lugares públicos en que las jóvenes sufren violencia e identificarán qué tipo de violencia ha sido la que sufrieron.

\section{MATERIALES:}

1. Libro Mi Voz, mi sueño, mi mundo

2. Hojas de trabajo Yo soy y Nosotras somos y queremos que lo sepan

3. Marcadores y papelógrafos

4. Cartel de los derechos de las mujeres, jóvenes y niñas indígenas

5. El mapa de Guatemala

6. Dos corazones de papel

\section{DESARROLLO DE LA SESIÓN}

\section{. Bienvenida a la sesión... Para fortalecer mi participación y pertenencia}

Dé la bienvenida a las participantes anunciando que tienen una visita especial de una niña que viene de otra parte del país y quiere compartir un poco de su vida con ellas. Escoja una historia del libro que permita a las niñas identificar similitudes en sus vidas (Una Rosa Nueva u otra). Cuente la historia a las niñas haciendo muchos gestos y animación de lectura. Al final, pida a las participantes que comente la historia: ¿Qué les gustó? ¿Qué emociones sintieron? ¿Qué tienen en común con la niña del cuento? En el mapa de Guatemala haga un corazón encima de Chisec y encima del departamento de dónde es originaria la niña de la historia. Invite a las participantes a que ellas también escriban una historia para dar a conocer sobre su vida y lo harán en la hoja "Yo soy" del cuaderno de trabajo. Permita suficiente tiempo para que escriban. Luego pida voluntarias que compartan sus historias y aplaudan fuertemente a las voluntarias. 


\section{Introducción al tema... mediante la reflexión sobre mi vida}

Luego de escuchar varias historias reflexione con las niñas sobre sus metas, sus deseos y sobre las oportunidades que quieren tener en su vida. Escriba sus respuestas en un papelógrafo titulado: "Nuestras metas, deseos y oportunidades" Explique que cada persona tiene el derecho de tomar decisiones que le permitan alcanzar sus metas, sus deseos y aprovechar las oportunidades que aparezcan en su vida y esa capacidad se llama autonomía. Presente la palabra en un cartel para ponerlo a la vista de las participantes. Pida que den ejemplos de cuando ellas han tomado decisiones para alcanzar sus metas, sus deseos y sus oportunidades.

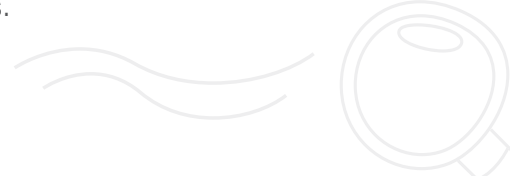

\section{Definición y teorización... de conceptos clave}

Cuente ahora la historia "Las cicatrices de mi vida" del libro Mi voz, mi sueño, mi mundo. Al finalizar reflexione con las participantes sobre quiénes tomaban decisiones sobre la vida de la niña y cuáles decisiones le hicieron daño pues limitaron sus oportunidades y derechos. Pueden referirse al cartel de los derechos de las mujeres, jóvenes y niñas indígenas para recordar cuáles son. Coloque un cartel al frente con la palabra violencia y pida que hagan una lluvia de ideas sobre qué es la violencia. Concluya al final que violencia son las acciones que limitan las oportunidades de una persona y le hacen daño a su dignidad.

A través de una dinámica forme cuatro grupos y entregue un cartel con un dibujo de un tipo de violencia a cada grupo. Pida que las participantes describan qué ven en el dibujo, cómo afecta la autoestima de la persona que recibe violencia, qué derechos u oportunidades le está limitando y como limita su autonomía. Recuerde adecuar el enfoque según la edad de las niñas.
Ejemplos de escenas de los tipos de violencia

- Violencia emocional: Un maestro gritándole a una alumna que es tonta y no puede estudiar.

- Violencia económica: Una joven que trabaja en una tortillería, pero es su padre quien recibe el dinero que pagan por su trabajo.

- Violencia física: Un hermano que pega a la hermana para que le sirva la comida.

- Violencia sexual: Un novio que obliga a la novia a darle un beso cuando ella no quiere.

El grupo 1 debe presentar su dibujo y las conclusiones a las que llegó, usted facilite a las participantes que identifiquen qué mensaje acerca de las niñas, jóvenes y mujeres se maneja en esa forma de violencia y apúntelo debajo del dibujo. Invite al debate sobre si el mensaje es cierto o falso. Luego pasa el siguiente grupo, hasta que todos los grupos han presentado.

\section{Aplicación a la vida... para transformar nuestras circunstancias}

Explique que van a crear mensajes que la comunidad debe conocer para ponerle fin a las formas de violencia que hay en la comunidad. Estos deben expresar ideas positivas sobre la autonomía de las mujeres, las relaciones en equilibrio y el fin de la violencia. Pida a las participantes formar grupos de trabajo y regresar a su cuaderno de trabajo para completar la página "Nosotras somos y queremos que lo sepan" en dónde escribirán tres mensajes. 


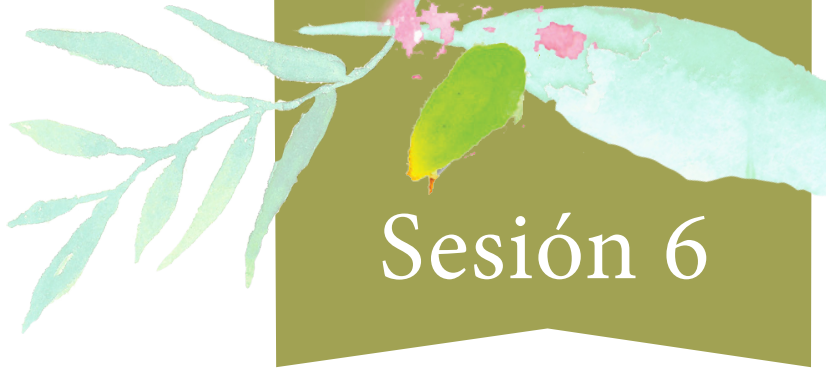

\section{Amo la dignidad}

\section{OB JETIVOS DE LA SESIÓN:}

- Las participantes conocen que el Estado de Guatemala ha emitido muchas leyes para proteger su dignidad poniendo fin a la violencia.

- Las identifican la Ley de Protección Integral de la Niñez y Adolescencia como una ley que protege su dignidad

- Las participantes explican qué significa el interés superior de la niña, niño y adolescente

\section{ENFOQUE POR GRUPO:}

8 a 12: Reconocen que tiene dignidad y por eso su familia, la escuela y su comunidad deben poner su bienestar y el de las demás niñas y niños como prioridad.

13 a 18: Reconocen que tienen dignidad y que el marco legal del país obliga a todas las entidades poner el bienestar y de las niñas, los niños, las jóvenes, los jóvenes como prioridad.

\section{MATERIALES:}

1. Papelógrafos y marcadores

2. Muñeca bebé

3. Papeles en forma de corazón

(u otra forma que represente la dignidad)

4. Extractos de la Ley de Protección Integral de la Niñez y Adolescencia

\section{DESARROLLO DE LA SESIÓN}

\section{Bienvenida a la sesión... Para fortalecer 1. mi participación y pertenencia}

Dan la bienvenida a cada una de las participantes, dándole la mano y un abrazo y al final ponen al centro a la muñeca y le dan la bienvenida también a ella. Les cuenta que es una invitada que represente a todas las niñas que están por nacer en Chisec Alta Verapaz y que tiene algo muy importante de aprender que ellas le han de enseñar.

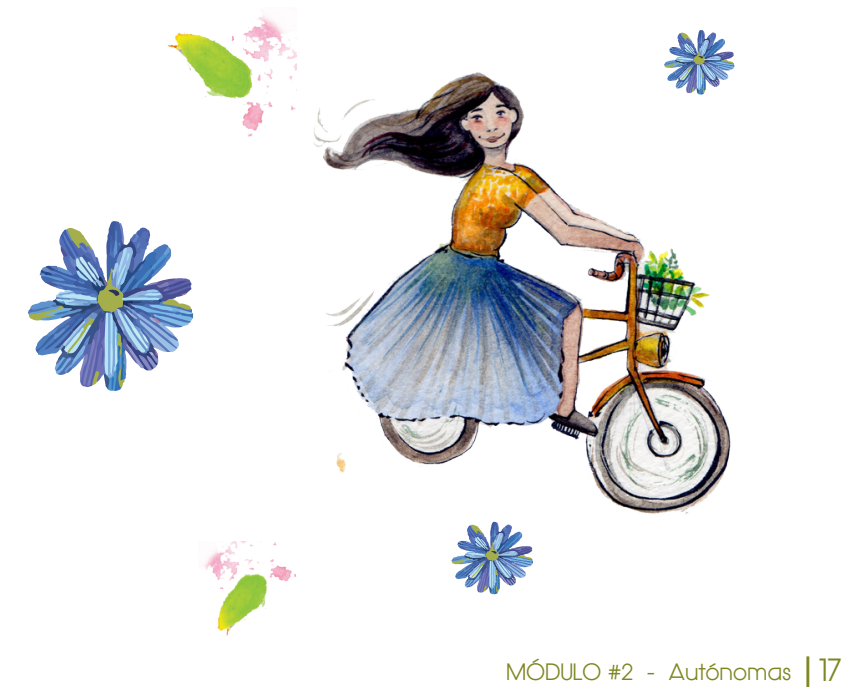




\section{Introducción al tema... mediante la reflexión sobre mi vida}

Coloca el papelógrafo al frente con la palabra dignidad y las invita a recordar qué es la dignidad, desde cuándo tenemos dignidad, qué derechos protegen la dignidad, quiénes tienen dignidad. Entregue los papeles en forma de corazón a las participantes, para que cada un escriba en un papel algo que le regala a esa niña que pueda proteger su dignidad y bienestar sobre todas las cosas. Pase la muñeca entre las participantes para que cada una la abrace y acaricie y le coloque el corazón en su cuerpo compartiéndole que le está entregando para proteger su dignidad.
Deje a la muñeca en un lugar especial y comparta con las participantes que el Estado de Guatemala, o sea el gobierno y su población, han acordado que es importante proteger la dignidad de las niñas y las mujeres para evitar que se les haga daño.

\section{Definición y teorización... de conceptos clave}

Coloque en un papelógrafo los nombres de las leyes que velan por la niñez, la adolescencia, las mujeres. Y explique que estas leyes se han hecho para hacer respetar la dignidad de las niñas, los niños, las adolescentes y las mujeres. Escriba en q'eqchi' "Toda la población debe velar por cuidar el interés superior de las niñas, los niños y adolescentes" pida que expliquen qué significa eso para ellas. Lea con ellas el artículo 5 de la Ley de Protección Integral de la niñez y adolescencia reflexionando con ellas sobre lo que significa en su vida.

Leyes a incluir en el papelógrafo:
- Convenio 182 de la OIT sobre la prohibición de las peores formas de trabajo infantil

- Protocolo para Prevenir, Reprimir y Sancionar la trata de Personas, especialmente niños y mujeres Convención Americana de Derechos Humanos

- Constitución Política de la República

- Ley de Protección Integral a la Niñez y Adolescencia

- Código Penal

- Ley para prevenir, erradicar y sancionar la violencia intrafamiliar

- Ley contra la violencia sexual, explotación y trata de personas

- Ley de acceso universal a los métodos de planificación familiar

- Ley contra el femicidio y otras formas de violencia en contra de la mujer

- Declaración universal de los derechos humanos

- Convención sobre los derechos del niño

- Convención contra todas las formas de discriminación en contra de la mujer

- Pacto Internacional de Derechos Económicos Sociales y Culturales

\section{Aplicación a la vida... para transformar nuestras circunstancias}

En el grupo de participantes de 8 a 12, forme grupos de trabajo y entregue a cada grupo un papelógrafo y marcadores. Ellas deberán hacer un dibujo de una situación que se da en su comunidad que provoca violencia en contra de las niñas. Al presentarlo la plenaria podrá ofrecer ideas sobre cómo debería ser y qué tiene que cambiar para defender y proteger el interés superior de las niñas.
En el grupo de participantes de 13 a 17, forme 4 grupos de trabajo y entregue un inciso del artículo 54 de la Ley de Protección Integral a la Niñez y Adolescencia a cada grupo. Ellas deberán escribir una historia del tipo de abuso que les tocó, escribiendo el final de la historia con la descripción de los cambios que se dieron en la comunidad para ponerle fin a ese abuso y proteger el interés superior de las adolescentes. 


\section{Introducción al tema... mediante la reflexión sobre mi vida}

Lidere una lluvia de ideas sobre las situaciones que pasan en la vida de las niñas y podrían ponerlas en riesgo o hacerles daño. Escriba estas situaciones en un papelógrafo. Si no sale, mencione las uniones y matrimonios forzados, así como los embarazos tempranos y la violencia sexual y económica. Pregunte porqué estas prácticas son dañinas para la dignidad de las niñas y adolescentes. Apunte las respuestas en un papelógrafo a la vista del grupo.

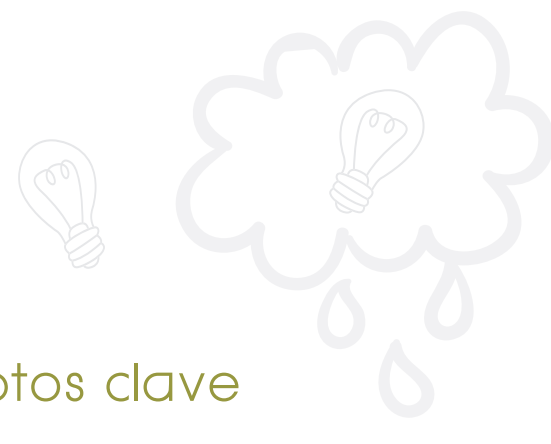

hasta que todas han entendido el decreto y tienen claridad de la norma.

1. ¿A partir de qué edad pueden casarse las jóvenes y los jóvenes?: 18 años

2. ¿Por qué se subió la edad de matrimonio a los 18 años?: Para proteger a las niñez y adolescencia de las consecuencias negativas del matrimonio temprano.

3. ¿Puede un papá o mamá autorizar el matrimonio de una joven antes de los 18 años?: No

4. ¿Pueden los menores de 18 años unirse?: No

5. ¿Qué personas están obligadas a protegerlas del matrimonio temprano? Padres de familia, madres de familia, jueces, COCODES, todos. las preguntas que están en la página 8 de su cuaderno de trabajo. Apunte las respuestas en un papelógrafo y juegue

\section{Aplicación a la vida... para transformar nuestras circunstancias}

Presente un papelógrafo gigante con el número 18 escrito en él. Puede decorarlo usando las manos de las participantes o escribiendo sus nombres dentro del número, pidiendo que ellas lo pinten. Sean creativas para que el 18 se resultado del trabajo de todas. Ese rótulo quedará a la vista del grupo para las próximas sesiones.
A cada una entregarán un número 18 para que se coloquen como gafete. Detrás del número deberán escribir todo lo que quieren hacer de aquí a que tengan 18 años. Lo pintarán o decorarán y se colocarán como gafete. 


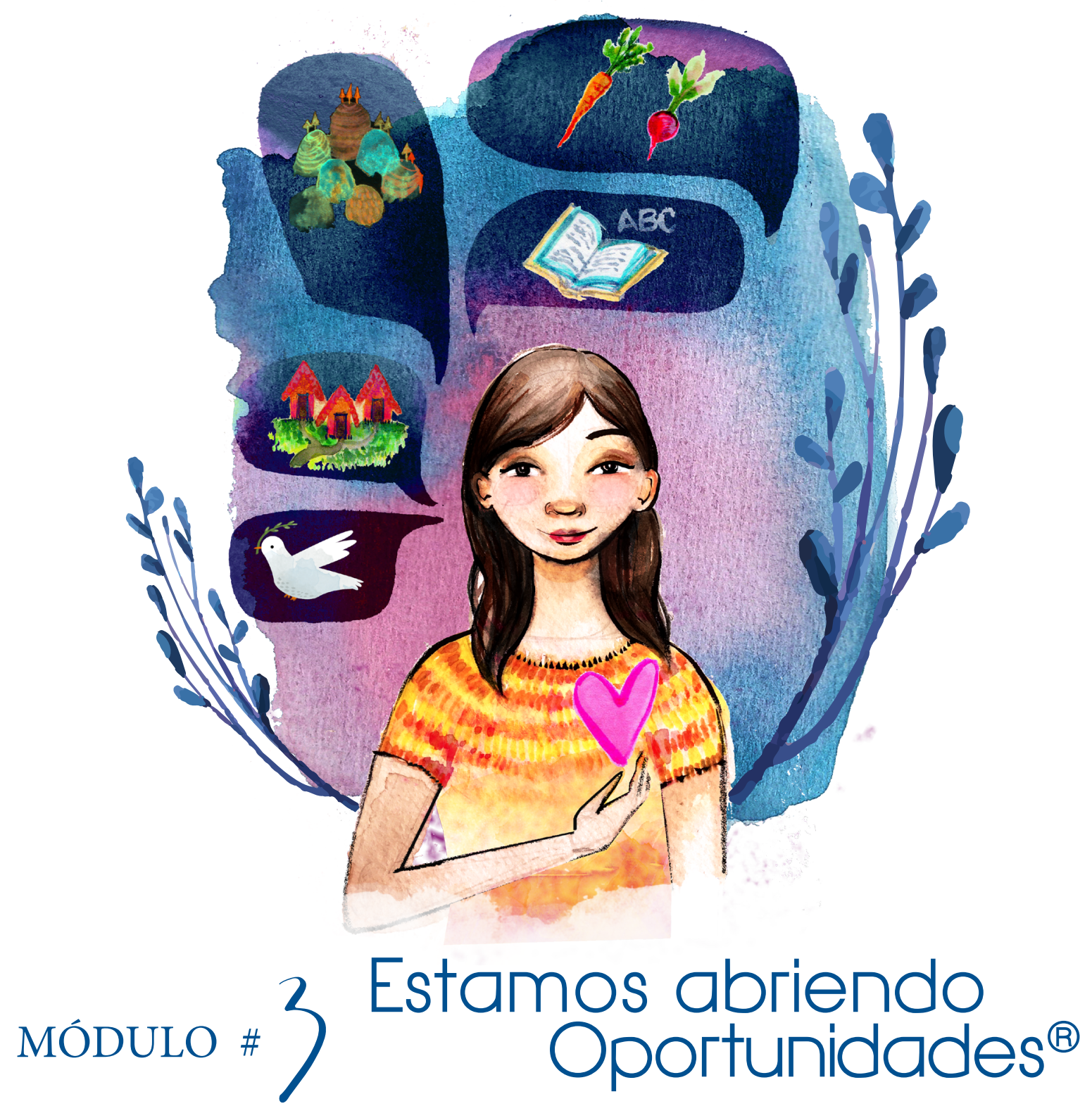

\author{
CON LA INCIDENCIA POLITICA PROVOCAMOS \\ CAMBIOS QUE BENEFICIAN A MUCHAS PERSONAS
}




\section{ESTAMOS ABRIENDO OPORTUNIDADES ${ }^{\circledR}$}

CON LA INCIDENCIA POLITICA PROVOCAMOS CAMBIOS QUE BENEFICIAN A MUCHAS PERSONAS

La ciudadanía activa se da a través de la participación en los asuntos de la comunidad, el municipio, el departamento y el país. El conocimiento sobre los derechos humanos es fundamental para que esa ciudadanía se convierta en la defensa, respeto y protección de los derechos de la colectividad. Estos son procesos que requieren de organización, equipo, planificación para generar cambios que mejoren las condiciones de vida de la comunidad. Para eso se realiza la incidencia política.

La incidencia es el arte de llevar a las personas hacia un propósito determinado. Cuando se logra persuadir a quienes toman decisiones sobre políticas, presupuestos y acciones se puede impactar la vida de un colectivo, eso es incidencia política. Se caracteriza por influir en las autoridades y personas clave con el objetivo de generar cambios en las políticas públicas, programas, presupuestos, leyes y acciones que llegan a afectar a miles de personas.

Para realizar incidencia política es necesario tener información estratégica, construir relaciones, formar alianzas y coaliciones con otros actores que comparten el mismo objetivo. Se debe definir con claridad la situación que se quiere modificar y el marco de leyes y normas que lo podrían transformar. Luego plantear qué cambio se quiere provocar para identificar aquellas personas que pueden tomar decisiones sobre las

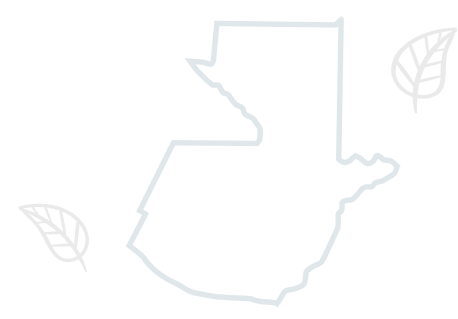

cuales se quiere influir mediante mensajes clave que tocan sentimientos, informan y llaman a la acción.

El conocimiento sobre los derechos humanos es fundamental para que esa ciudadanía se convierta en la defensa, respeto y protección de los derechos de la colectividad.

Pasos para la incidencia política:

1. Identificar el problema: ¿Cuál es la situación que se quiere modificar?

2. Trazar el objetivo de la incidencia: ¿Qué se quiere lograr?

3. Investigar y conocer sobre la situación: ¿Qué información hay sobre la situación que queremos modificar?

4. Identificar la política, ley o programa sobre el que se quiere hacer incidencia

5. Delimitar y conocer las audiencias: ¿Qué personas tienes capacidad de decisión en esta situación?

6. Construir los mensajes para cada audiencia: ¿Qué mensajes se dará a cada actor?

7. Planear y prepararse para la acción de incidencia polítca: ¿Cómo vamos a presentar los mensajes?

8. Evaluación: ¿Qué se alcanzó?

¿Por qué se alcanzó ese cambio? 


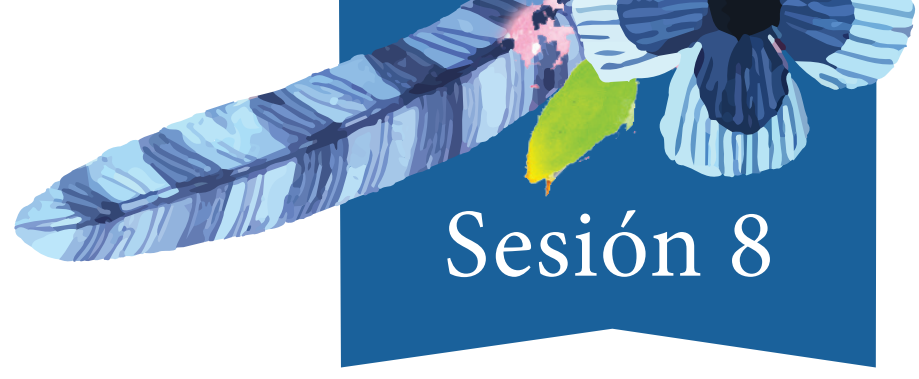

\section{Incidencia política para la transformación}

\section{OBJETIVOS DE LA SESIÓN:}

- Las participantes conocen qué es la incidencia política.

- Las participantes establecen el cambio que quieren lograr y el mapeo.

- Las participantes construyen mensajes convincentes para la incidencia política

\section{ENFOQUE POR GRUPO:}

8 a 12: Pueden influir en las decisiones de su familia si les dan información y mensajes acertados de la mejor forma.

13 a 18: Pueden influir en las decisiones del COCODE para mejorar la vida de todas las niñas, adolescentes y mujeres en su comunidad.

\section{DESARROLLO DE LA SESIÓN}

\section{Bienvenida a la sesión... Para fortalecer 1. mi participación y pertenencia}

Arranca la sesión con la dinámica Abrazos que regalan futuro. Cada participante va escribir tres papeles con una oportunidad que quieren tener en su futuro. Luego con música alegre de fondo van a caminar por el salón libremente para que cuando la música termine rápidamente encuentren a una compañera a quien abrazar y con el abrazo le regalan uno de sus tres papeles con oportunidad para el futuro.

\author{
MATERIALES: \\ 1. Cuaderno de trabajo \\ 2. 3 papeles para cada participante \\ 3. Canasta decorada \\ 4. Papelógrafo y marcadores
}

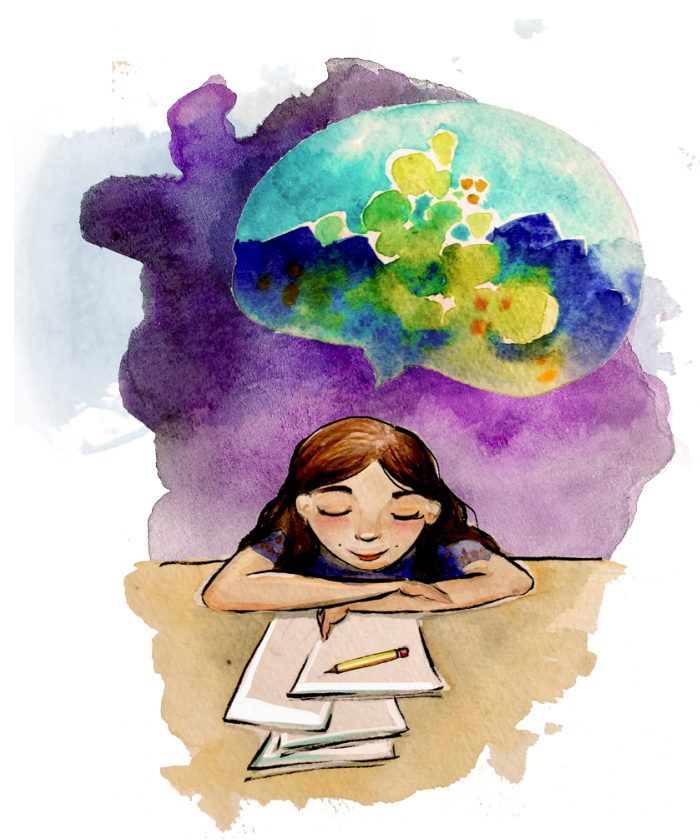




\section{Introducción al tema... mediante la reflexión sobre mi vida}

Al terminar reflexionan en plenaria sobre las siguientes preguntas:

a. ¿Cómo será su vida si tienen todas las oportunidades que han recibido esta mañana?

b. ¿Cuáles son las oportunidades más difíciles de asegurar para todas las niñas y adolescentes?

c. ¿Qué hay que modificar para que esas oportunidades lleguen a todas? d. ¿Cómo limitan los matrimonios y las uniones forzadas las oportunidades para las niñas y adolescentes?

Ponga una gran canasta al centro decorada muy linda y pida que coloquen allí los papeles que recibieron. Diga que esa es la canasta de sus metas, del futuro que quieren y van a conseguirse trabajando en conjunto para mejorar la vida de todas las niñas y adolescentes de la comunidad.

\section{Definición y teorización... de conceptos clave}

Presente en un papelógrafo la definición de incidencia y permita que lo lean, comentando qué piensan sobre la misma, si es posible que hagan incidencia, con qué autoridades tienen ellas contacto, quiénes se pueden beneficiar si ellas se organizan para hacer incidencia, cuáles serían las principales situaciones que quieren cambiar al hacer incidencia.

Pida una lluvia de ideas sobre acciones para cambiar la presión sobre las adolescentes a casarse en la comunidad. Luego de que tengan esa listapida que detallen a qué personas tienen que alcanzar y porqué cada persona es importante en el proceso para detener el matrimonio temprano. Puede ir apuntando todo en un papelógrafo para ir formando una tabla como la siguiente:

\begin{tabular}{|c|c|c|}
\hline $\begin{array}{c}\text { ACCIONES A } \\
\text { REALIZAR }\end{array}$ & $\begin{array}{c}\text { PERSONAS A } \\
\text { INVOLUCRAR }\end{array}$ & $\begin{array}{c}\text { CÓMO ACTÚA } \\
\text { CADA PERSONA }\end{array}$ \\
\hline & & \\
\hline & & \\
\hline
\end{tabular}

Resalte que en la incidencia política la construcción de los mensajes que se van a dar es muy importante porque puede convencer a la persona de modificar sus decisiones. Explique que cada mensaje debe llevar tres elementos: 1. Información acerca de la importancia de cambiar su conducta, 2. Anécdotas o historias que provoquen empatía en la persona que se quiere influir y 3. Una solicitud de cómo debe actuar. Puede construir con ellas algunos mensajes de ejemplo sobre otros temas que no sean el matrimonio temprano.

1. La ausencia de centros escolares de básicos dificulta que las jóvenes sigan estudiando más allá de la primaria.

2. Muchas de nuestras mamás no pudieron seguir estudiando a pesar de que les hubiera gustado mucho para su desarrollo personal.

3. Es importante que usted como COCODE gestione ante la municipalidad la apertura de centros escolares.

\section{Aplicación a la vida... para transformar nuestras circunstancias}

Formarán grupos asignando uno de los actores de los que ellas enumeraron a cada grupo. En su grupo deberán construir un mensaje clave que motive a esa persona a parar el matrimonio y las uniones forzadas tempranas incluyendo 1. Información acerca de la importancia de cambiar su conducta, 2. Anécdotas o historias que provoquen empatía en la persona que se quiere influir y 3. Una solicitud de cómo debe actuar. 


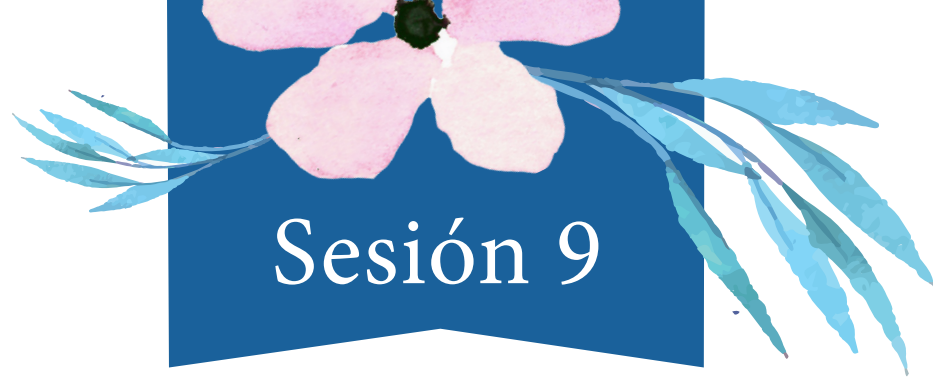

\section{Pesos pesados en incidencia política}

\section{OBJETIVOS DE LA SESIÓN:}

- Las participantes conocen los pasos de incidencia política.

- Las participantes llenan un plan de una acción de incidencia política.

- Las participantes se preparan para la realización de una acción de incidencia política.

\section{DESARROLLO DE LA SESIÓN}

\section{Lienvenida a la sesión... Para fortalecer - mi participación y pertenencia}

Realizar un juego con las participantes que les permita convivir y divertirse entre ellas mientras trabajan en equipo. Puede ser usando elementos de su entorno, sean naturales o desechables, construirán la torre más alta que puedan. La torre debe ser además fuerte.

\section{ENFOQUE POR GRUPO:}

8 a 12: Realizarán una acción de incidencia frente a las autoridades de su familia y de la escuela.

13 a 18: Realizarán una acción de incidencia frente a las autoridades del COOCDE.

MATERIALES:

1. Cuaderno de trabajo

2. Papelógrafos

3. Calendario

2. Introducción al tema... mediante la

Al terminar el juego se reflexiona sobre la forma en que planificaron cómo construir su torre y que pasos siguieron para alcanzar la meta. Apunte sus ideas en un papelógrafo. Luego comparta que van a realizar una acción de incidencia en su comunidad para comunicar sus mensajes construidos la semana previa. 


\section{Definición y teorización... de conceptos clave}

Presente en un papelógrafo los pasos para realizar incidencia política, mientras va comentando con ellas lo que significa cada paso y cómo algunos de estos ya se han realizado a lo largo de las reuniones previas.

\section{PASOS PARA LA INCIDENCIA POLÍTICA:}

1. Identificar el problema: ¿Cuál es la situación que se quiere modificar?

2. Trazar el objetivo de la incidencia: ¿Qué se quiere lograr?

3. Investigar y conocer sobre la situación: ¿Qué información hay sobre la situación que queremos modificar?

4. Identificar la política, ley o programa sobre el que se quiere hacer incidencia.

5. Delimitar y conocer las audiencias: ¿Qué personas tienes capacidad de decisión en esta situación?

6. Construir los mensajes para cada audiencia: ¿Qué mensajes se dará a cada actor?

7. Planear y prepararse para la acción de incidencia polítca: ¿Cómo presentar los mensajes?

8. Evaluación: ¿Qué se alcanzó? ¿Por qué se alcanzó ese cambio?
Pida que trabajen juntas su plan para la acción de incidencia política. Cada una apuntará en su cuaderno de trabajo mientras usted lo hace a la vista de todas en el papelógrafo.

\begin{tabular}{|l|}
\hline PLAN DE INCIDENCIA POLÍTICA \\
\hline Título de la acción: \\
\hline Tipo de acción: \\
\hline Fecha de realización de la acción: \\
\hline Objetivo de incidencia: \\
\hline Mensaje central: \\
\hline Personas objetivo invitadas: (nombre, cargo) \\
\hline Personas audiencia invitadas: (nombre) \\
\hline $\begin{array}{l}\text { Agenda a seguir el día de la acción: } \\
\text { (actividad, persona, tiempo, material) }\end{array}$ \\
\hline Forma de realizar la convocatoria y confirmación: \\
\hline
\end{tabular}

\section{Aplicación a la vida... para transformar nuestras circunstancias}

Una vez llenado el plan de incidencia política deberán organizarse ente ellas para asignar responsabilidades y fechas para cumplir con las tareas que les corresponden. Lo puede dejar organizado en una tabla como la siguiente:

\begin{tabular}{|l|l|l|l|}
\hline \multicolumn{1}{|c|}{ TAREA } & MATERIALES & PERSONA RESPONSABLE & FECHA PARA REALIZARLA \\
\hline Convocar a invitados & & & \\
\hline Convocar a líderes & & & \\
\hline Preparación de Materiales de puntos de & & & \\
\hline $\begin{array}{l}\text { Preparación de los } \\
\text { agenda }\end{array}$ & & & \\
\hline Animación y facilitación de la reunión & & & \\
\hline $\begin{array}{l}\text { Confirmar la participación de } \\
\text { autoridades la participación de }\end{array}$ & & & \\
\hline $\begin{array}{l}\text { Confirmar la } \\
\text { personas invitadas }\end{array}$ & & & \\
\hline $\begin{array}{l}\text { Registro de lo sucedido durante la } \\
\text { reunión y acuerdos alcanzados }\end{array}$ & & & \\
\hline
\end{tabular}




\section{EVALUACIÓN}

\begin{tabular}{|c|c|c|}
\hline INDICADOR & \multicolumn{2}{|c|}{ CALIFICACIÓN } \\
\hline $\begin{array}{l}\text { 1. Se logró la asistencia de las autoridades } \\
\text { convocadas }\end{array}$ & Sí & No \\
\hline $\begin{array}{l}\text { 2. El mensaje central fue repetido varias } \\
\text { veces a lo largo de la reunión }\end{array}$ & Sí & No \\
\hline $\begin{array}{l}\text { 3. Las autoridades tuvieron claro qué se les } \\
\text { está pidiendo que realicen }\end{array}$ & Sí & No \\
\hline $\begin{array}{l}\text { 4. Se logró el objetivo de la acción de } \\
\text { incidencia política }\end{array}$ & Sí & No \\
\hline $\begin{array}{l}\text { 5. Las actividades realizadas fueron interesantes } \\
\text { para las autoridades invitadas }\end{array}$ & Sí & No \\
\hline $\begin{array}{l}\text { 6. Las autoridades se comprometieron con el } \\
\text { grupo }\end{array}$ & Sí & No \\
\hline
\end{tabular}

\section{AUTOEVALUACIÓN}

\begin{tabular}{|c|c|c|}
\hline INDICADOR & \multicolumn{2}{|c|}{ CALIFICACIÓN } \\
\hline $\begin{array}{l}\text { 1. Cumplí a cabalidad con la tarea que me } \\
\text { fue asignada }\end{array}$ & Sí & No \\
\hline $\begin{array}{l}\text { 2. Aprendí información sobre el tema que se está } \\
\text { trabajando en la acción política de incidencia }\end{array}$ & Sí & No \\
\hline $\begin{array}{l}\text { 3. Me relacioné con las autoridades antes, durante } \\
\text { y/o después de la acción de incidencia política }\end{array}$ & Sí & No \\
\hline $\begin{array}{l}\text { 4. Participé y apoyé en la realización de la acción } \\
\text { de incidencia política }\end{array}$ & Sí & No \\
\hline
\end{tabular}




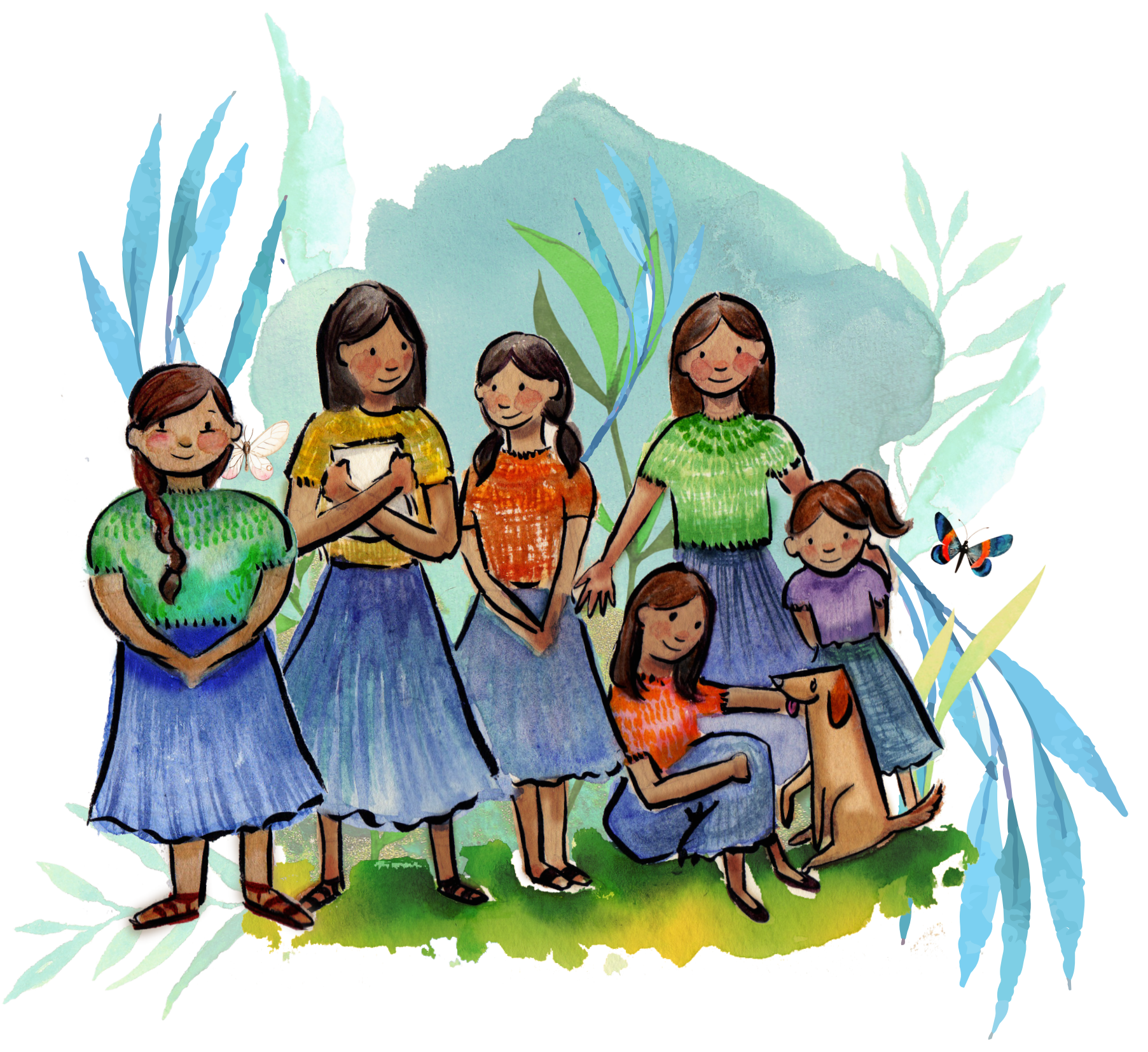

